\title{
Stability of Advanced Medium Duration Genotypes Across Seasons for Yield in Pigeonpea [Cajanus cajan (L.) Millsp.]
}

\author{
S. Muniswamy ${ }^{1}$, Praveen Kumar ${ }^{1}$, Rachit K. Saxena ${ }^{2}$, Geeta ${ }^{1}$, Rajeev K. Varshney ${ }^{2}$
}

10.18805/IJARe.A-5739

\begin{abstract}
Background: Yield is polygenically inherited and highly influenced by $G \times E$ interaction higher magnitude of $G \times E$ interaction among genotypes invalidates the fitness of genotypes across the environments. Hence, quantification $G \times E$ interaction and identification of stable genotypes across environments will enhance production and productivity of pigeonpea.

Methods: The stable performance of the thirty three advanced medium duration lines of pigeonpea along with six check varieties across the seasons were examined during kharif-2017, 2018 and 2019 at Zonal Agricultural Research Station, (ZARS) Kalaburagi, Karnataka, India. The advanced medium duration genotypes was contributed by six research stations belongs six states in India. Result: Considering all stability parameters the genotype ICPL 20108 found stable, high yielding and had desirable agronomic traits. The genotype GRG 177 though ranked first for mean yield, it exhibited nonlinear regression indicating highly sensitiveness to different environments. The genotype GRG 152 had second highest mean yield with $\mathrm{bi}<1$ (bi= regression) and non significant deviation from regression co-efficient indicating its specific suitability to unfavorable/poor/low input environments. The genotypes BDN-2014-1, ICPL 20098 and AGL-1603-4 had average yield above population mean and exhibited stable performance across environments.
\end{abstract}

Key words: $G \times E$ interaction, Pigeonpea, Regression co-efficient, Stability.

\section{INTRODUCTION}

Pigeonpea [Cajanus cajan (L.) Millsp.] is commonly known as redgram or arhar or tur or thogari in India. It is an important grain legume that originated in the India (Varshney et al., 2017). It is grown in many parts of the world including Southern Africa particularly the region encompassing Kenya, Mozambique, Malawi and Southern Tanzania (Hogh-Jensen et al. 2007). It ranks sixth in global grain legume production and worldwide it is cultivated in about more than $5.0 \mathrm{~m}$ ha area. India is the largest producer and consumer of pigeonpea with an area of $4.4 \mathrm{~m}$ ha, with annual production of $3.68 \mathrm{~m}$ t and productivity of $832 \mathrm{~kg} / \mathrm{ha}$ (Anonymous 2019).

Pigeonpea breeders look forward for widely adapted genotypes which are responsive to input intensive as well as input deficient agriculture in order to enhance production and productivity of the crop. Selection and yield testing are the two major phases of varietal development and the later one is highly influenced by the locations and years of testing. Yield is polygenically inherited and highly influenced by $G \times E$ interaction.higher magnitude of $G \times E$ interaction among genotypes invalidates the fitness of genotypes across the environments. Hence, quantification $G \times E$ interaction and identification of stable genotypes across environments will enhance production and productivity of pigeonpea. With this back ground the present study was undertaken under rainfed situation in three seasons/ years to identify stable genotypes of pigeonpea for seed yield.

\section{MATERIALS AND METHODS}

The present experiment comprised of thirty three advanced medium duration lines of pigeonpea along with six check varieties received from seven research institute viz., (a)
'Zonal Agricultural Research Station, Kalaburagi-585 101, Karnataka, India.

${ }^{2}$ International Crops Research Institute for the Semi-Arid Tropics, Patancheru-502 324, Telangana, India.

Corresponding Author: S. Muniswamy, Zonal Agricultural Research Station, Kalaburagi-585 101, Karnataka, India.

Email: muniswamygpb@gmail.com

How to cite this article: Muniswamy, S., Kumar, P., Saxena, R.K., Geeta and Varshney, R.K. (2022). Stability of Advanced Medium Duration Genotypes Across Seasons for Yield in Pigeonpea [Cajanus cajan (L.) Millsp.]. Indian Journal of Agricultural Research. DOI: 10.18805/IJARe.A-5739.

Submitted: 18-01-2021 Accepted: 06-01-2022 Online: 08-03-2022

ICRISAT, Hyderabad, (b) Regional Agricultural Research Station (RARS), Lam, Andhra Pradesh, (c) Agricultural Research Station (ARS), Badnapur, Maharashtra, (d) RAKCA, Sehore, Madhya Pradesh, (e) Indian Institute of Pulse Research (IIPR), Kanpur, Uttar Pradesh, (f) PJTSAU, Tandur, Telangana and (g) ZARS, Kalaburagi, Karnataka. The list and source of genotypes is presented in the Table 1. The trials were conducted in a randomized block design with two replications in three season/ year viz., kharif-2017 $\left(E_{1}\right)$, kharif-2018 $\left(E_{2}\right)$ and kharif-2019 $\left(E_{3}\right)$, under rainfed condition at Zonal Agriculture Research Station (ZARS), Kalaburagi, which is situated in agro-climatic zone-2 (North Eastern Dry Zone) of Karnataka state with $17^{\circ} 20^{\prime}$ Latitude (N), $76^{\circ} 49^{\prime}$ Longitude (E) and at an altitude of 443.88 meters above mean sea level. The rainfall pattern of three environments is presented in Annexure-I. The plot size of four rows each with $4 \mathrm{~m}$ length was followed with spacing of 
Table 1: The list and source of advanced medium duration genotypes.

\begin{tabular}{lcl}
\hline Source & No. of genotypes & Name of the genotypes \\
\hline ICRISAT, Hyderabad & 13 & $\begin{array}{l}\text { ICPL-20096, ICPL-20098, ICPL-20103, ICPL-20108, ICPL-99050, } \\
\text { ICPL-20116, ICPH-2671, ICPH-2740, ICPH-3933, ICPH-3762, AGL- } \\
\end{array}$ \\
& 4 & $\begin{array}{l}\text { 1603-4, Maruti (Check) and Asha (Check). } \\
\text { LAXMI, LRG-41, LRG-105 and LRG-160 }\end{array}$ \\
RARS, Lam, Andhra Pradesh & 6 & BDN-2014-1, BDN-2011-1, BDN-2013-41, BDN-2014-2, BDN-2013-45 \\
ARS, Badnapur, Maharashtra & & and BDN-711 (Check) \\
& 5 & RVSA-15-5, RVSA-15-6, RVSA-15-10, TJT-501 and JKM-189 (Check) \\
RAKCA, Sehore, Madhya Pradesh & 4 & IBTDREG-3, IBTDRG-4, IBTDRG-6 and IBTDRG-5 \\
IIPR, Kanpur, Uttar Pradesh & 3 & TDRG-60, TDRG-58 and TDRG-4 (Check) \\
PJTSAU, Tandur, Telangana & 4 & GRG-177, GRG-152, GRG-333 and TS-3R (Check) \\
ZARS, Kalaburagi, Karnataka & &
\end{tabular}

$90 \mathrm{~cm}$ between rows and $25 \mathrm{~cm}$ between the plants. Standard agronomic practices were followed and plant protection measures were taken as and when required as per package of practices (Anonymous. 2017). Observations were recorded on five randomly selected plants in each replication in each environment with respect to days of $50 \%$ flowering, maturity, plant height $(\mathrm{cm})$ at maturity, 100 seed weight and seed yield per plant and seed yield per plot. Seed yield being the economic trait, it was converted to per hectare yield and used to find out stability parameters viz., mean, regression co-efficient (bi) and mean square deviation (S2di) as per stability model proposed by Eberhart and Russel (1966) using statistical analysis package software Windostat 9.2.

\section{RESULTS AND DISCUSSION}

Pooled ANOVA for stability of seed yield tonnes per hectare is given in Table 2. Genotype $\times$ environmental interaction as per Eberhart and Russell's (1966) model indicated that, Environment linear component was highly significant for seed yield, whereas, $G \times E$ (linear) interaction was nonsignificant for the character. These findings are in agreement with the earlier findings of Ghodke (1992) obtained non significant $G \times E$ for majority of the traits. Further, higher value of mean squares due to environment (linear) as compared to genotype $\mathrm{x}$ environment (linear) displayed that linear response of environments accounted for the most of total variation for the trait under study. Similar findings in this regard were obtained by Kumara et al. (2015). As regard to pooled deviation (nonlinear portion of variance), which is unpredictable portion of $G \times E$ interaction was highly significant for the trait under study. This demonstrated that genotypes respond differently to variation in environmental condition, indicated that the deviation from linear regression also contributed substantially toward the differences in stability of genotypes. The results are in accordance with Balakrishna and Natarajratnam (1989); Sawargaokar et al. (2011); Pawar et al. (2013); Patel and Tikka (2014); Kumara et al. (2015); Singh et al. (2015); Meena et al. (2017); Ramesh et al. (2017) and Deepak Pal et al. (2020).

As indicated in the Table 3, the genotype GRG-177 showed highest seed yield (1.18 t/ha). While, IBTDRG-4
Table 2: Pooled MSS values for quantitative trait (Seed yield $t / h a$ ) over three Seasons/Environments / years.

\begin{tabular}{lcc}
\hline Source of Variation & DF & Seed yield (t/ha) \\
\hline Rep within Env. & 3 & 0.031 \\
Varieties & 38 & 0.058 \\
Env.+ (Var.* Env.) & 78 & 0.119 \\
Environments & 2 & $1.739 * * *$ \\
Var. $^{*}$ Env. & 76 & 0.076 \\
Environments (Lin.) & 1 & $3.479 * * *$ \\
Var.* Env.(Lin.) & 38 & 0.072 \\
Pooled Deviation & 39 & $0.078^{* * *}$ \\
Pooled Error & 114 & 0.014 \\
Total & 116 & 0.099 \\
\hline
\end{tabular}

* and ${ }^{* *}$ significant at $5 \%$ and $1 \%$ level of probability respectively.

Annexure I: Rain fall pattern of the year 2017,2018, 2019 and average rainfall $(\mathrm{mm})$ at ZARS, Kalaburag

\begin{tabular}{lccc}
\hline Months/tears & 2017 & 2018 & 2019 \\
\hline May & 7.0 & 57.8 & 23 \\
June & 239.2 & 55.2 & 117.4 \\
July & 85.8 & 74.1 & 73.8 \\
August & 100.9 & 106.6 & 122.6 \\
September & 357.0 & 116 & 291 \\
October & 124.0 & 31.2 & 105.8 \\
November & 0.0 & 0 & 0 \\
December & 0.0 & 127.4 & 9.2 \\
Total rain fall $(\mathrm{mm})$ & 913.9 & 568.3 & 742.8 \\
\hline
\end{tabular}

less seed yield (0.54 t/ha) and population mean over three environments was $0.93 \mathrm{t} / \mathrm{ha}$. All the genotypes showed nonsignificant value for regression coefficient and deviation from regression. The 23 genotypes viz., GRG-177, GRG-152, ICPH-3762, TS-3R (check), ICPL-20108, Asha (check), ICPH-2671, ICPH-2740, ICPL-99050, RVSA-15-5, ICPL20116, LRG-105, BDN-2011-1, RVSA-15-10, IBTDREG-3, ICPL-20098, BDN-2013-45, TDRG-58, IBTTDRG-5, AGL1603-4, IBTDRG-6, ICPH-3933 and TDRG-60 were found to have higher mean value than population mean with non significant bi and $S^{2} d_{i}$ values. 
The genotype GRG 177 though showed highest yield, it exhibited nonlinear regression indicating highly sensitiveness to different environments. The genotype GRG 152 had second highest mean yield with positive regression (0.52) and non significant deviation from regression coefficient indicating the its specific suitability to unfavorable environments. Considering all stability parameters the genotype ICPL 20108 considered as stable and high yielding because it had high mean yield (1.07 t/ha) regression coefficient around unity $(\mathrm{bi}=0.94)$ and non significant deviation from $S^{2} d_{i}$ In addition to stable performance of the variety ICPL 20108, it had ideal agronomic traits like medium maturity (160 days) and test weight (10.6 g/100 seeds). The average performance of genotypes for agronomic traits over three years is presented in Table 4. The genotypes ICPL 20098 and AGL-1603-4 (0.94

Table 3: Mean and stability parameters in 39 advanced genotypes of pigeon pea.

\begin{tabular}{|c|c|c|c|c|c|c|c|}
\hline \multirow{2}{*}{ Genotypes } & \multicolumn{3}{|c|}{ Environment wise seed yield $t /$ ha } & \multicolumn{2}{|c|}{ Seed yield $\mathrm{t} / \mathrm{ha}$} & \multirow[b]{2}{*}{ bi } & \multirow[b]{2}{*}{$\mathrm{S}^{2} \mathrm{di}$} \\
\hline & $\mathrm{E}_{1}$ & $\mathrm{E}_{2}$ & $\mathrm{E}_{3}$ & Mean & Rank & & \\
\hline ICPL-20096 & 0.98 & 1.00 & 0.77 & 0.91 & 25 & -0.53 & -0.01 \\
\hline ICPL-20098 & 0.61 & 1.24 & 1.05 & 0.97 & 16 & 0.91 & 0.12 \\
\hline ICPL-20103 & 0.63 & 0.89 & 0.75 & 0.75 & 36 & 0.23 & 0.01 \\
\hline ICPL-20108 & 0.73 & 1.29 & 1.18 & 1.07 & 5 & 0.94 & 0.08 \\
\hline ICPL-99050 & 0.97 & 1.39 & 0.77 & 1.04 & 9 & -0.63 & 0.15 \\
\hline ICPL-20116 & 0.54 & 1.57 & 0.95 & 1.02 & 11 & 0.73 & 0.48 \\
\hline ICPH-2671 & 0.78 & 1.01 & 1.38 & 1.06 & 7 & 1.43 & -0.01 \\
\hline ICPH-2740 & 0.96 & 1.18 & 1.01 & 1.05 & 8 & 0.06 & 0.01 \\
\hline ICPH-3933 & 0.39 & 1.30 & 1.11 & 0.93 & 22 & 1.53 & 0.23 \\
\hline ICPH-3762 & 1.02 & 1.30 & 1.10 & 1.14 & 3 & 0.1 & 0.03 \\
\hline LAXMI & 0.74 & 0.41 & 1.12 & 0.75 & 35 & 1.05 & 0.14 \\
\hline BDN-2014-1 & 0.80 & 0.46 & 1.41 & 0.89 & 26 & 1.63 & 0.21 \\
\hline BDN-2011-1 & 1.01 & 0.68 & 1.32 & 1.00 & 13 & 0.88 & 0.12 \\
\hline BDN-2013-41 & 0.38 & 0.98 & 1.23 & 0.86 & 30 & 1.95 & 0.03 \\
\hline BDN-2014-2 & 0.25 & 1.22 & 1.30 & 0.92 & 24 & 2.34 & 0.18 \\
\hline BDN-2013-45 & 0.60 & 0.96 & 1.32 & 0.96 & 17 & 1.68 & -0.01 \\
\hline RVSA-15-5 & 0.69 & 1.03 & 1.38 & 1.03 & 10 & 1.61 & -0.01 \\
\hline RVSA-15-6 & 0.31 & 0.57 & 1.28 & 0.72 & 37 & 2.35 & 0 \\
\hline RVSA-15-10 & 0.74 & 0.83 & 1.44 & 1.00 & 14 & 1.72 & 0.01 \\
\hline TJT-501 & 0.39 & 0.82 & 1.42 & 0.88 & 28 & 2.46 & -0.01 \\
\hline IBTDREG-3 & 0.80 & 0.89 & 1.27 & 0.98 & 15 & 1.16 & -0.01 \\
\hline IBTDRG-4 & 0.33 & 0.48 & 0.83 & 0.54 & 39 & 1.22 & -0.01 \\
\hline IBTDRG-6 & 0.57 & 0.78 & 1.47 & 0.94 & 21 & 2.19 & 0 \\
\hline TDRG-60 & 0.64 & 0.89 & 1.27 & 0.93 & 23 & 1.51 & -0.01 \\
\hline TDRG-58 & 0.72 & 0.76 & 1.40 & 0.96 & 18 & 1.69 & 0.02 \\
\hline IBTTDRG-5 & 0.94 & 0.77 & 1.16 & 0.95 & 19 & 0.62 & 0.03 \\
\hline LRG-4 1 & 0.26 & 0.80 & 1.33 & 0.80 & 32 & 2.52 & -0.01 \\
\hline LRG-105 & 0.91 & 1.04 & 1.08 & 1.01 & 12 & 0.39 & -0.01 \\
\hline LRG-160 & 0.24 & 0.75 & 0.99 & 0.66 & 38 & 1.72 & 0.01 \\
\hline GRG-177 & 1.37 & 0.86 & 1.30 & 1.18 & 1 & -0.02 & 0.14 \\
\hline GRG-152 & 1.15 & 0.99 & 1.34 & 1.16 & 2 & 0.51 & 0.02 \\
\hline GRG-33 3 & 1.04 & 0.73 & 0.69 & 0.82 & 31 & -0.79 & 0 \\
\hline AGL-1603-4 & 0.75 & 0.91 & 1.16 & 0.94 & 20 & 0.99 & -0.01 \\
\hline BDN-711 $(\mathrm{CH})$ & 0.86 & 0.61 & 0.89 & 0.79 & 33 & 0.16 & 0.03 \\
\hline JKM-189 (CH) & 0.61 & 0.82 & 1.22 & 0.88 & 27 & 1.48 & -0.01 \\
\hline TDRG-4 (CH) & 0.67 & 0.44 & 1.17 & 0.76 & 34 & 1.32 & 0.11 \\
\hline TS-3R $(\mathrm{CH})$ & 1.40 & 0.63 & 1.31 & 1.11 & 4 & 0.02 & 0.34 \\
\hline MARUTI $(\mathrm{CH})$ & 0.91 & 0.70 & 0.99 & 0.87 & 29 & 0.27 & 0.03 \\
\hline $\mathrm{ASHA}(\mathrm{CH})$ & 0.99 & 1.33 & 0.87 & 1.06 & 6 & -0.41 & 0.09 \\
\hline Population Mean & 0.733 & 0.902 & 1.153 & 0.93 & & & \\
\hline
\end{tabular}

$\mathrm{E}_{1}=$ Kharif 2017 ZARS Kalaburgi; $\mathrm{E}_{2}=$ Kharif 2018 ZARS Kalaburgi; $\mathrm{E}_{3}=$ Kharif 2019 ZARS Kalaburgi. 
t/ha) had average yield above population mean, regression around unity and non significant deviation from $S^{2} d_{i}$ indicating stableness of these genotypes across the environments. The agronomic characters of these genotypes also found ideal (Table 4). The check entry TS $3 R$ and the hybrid ICPH 2740 had high mean with bi value less than one (i.e around zero) and non asignificant $S^{2} d_{i}$ indicating their suitability to unfavorable or low input environments. Referring to the ancillary traits (Table 4), the genotypes TDRG 60, IBTTDRG-5 and BDN-2013-45 were early maturing and had average yield above population mean. The entry LRG 41 was bold seeded genotype.

Environmental index (EI) refers to a variety that has response across environments that is parallel to the mean response of all genotypes in the trial (i.e. the mean regression on the environmental index). The regression of genotypes for seed yield (t/ha) across environments and stability parameters is presented in Fig 1. As indicated by El, the genotypes TDRG 60, AGL 1603-4, ICPH 2671, JKM 189 (Ch), RVSA-15-5 and BDN-2013-45 had linear

Table 4: Ancillary traits of the genotypes averaged over three years.

\begin{tabular}{|c|c|c|c|c|}
\hline Genotypes & Days to $50 \%$ flowering & $75 \%$ maturity & Plant height $(\mathrm{Cm})$ & 100 seed weight $(\mathrm{Gr})$ \\
\hline ICPL-20096 & 108.6 & 158.6 & 150.3 & 13.3 \\
\hline ICPL-20098 & 112.5 & 166.8 & 150.0 & 10.8 \\
\hline ICPL-20103 & 104.5 & 156.8 & 146.8 & 11.2 \\
\hline ICPL-20108 & 106.6 & 160.5 & 138.3 & 10.6 \\
\hline ICPL-99050 & 103.8 & 158.5 & 129.8 & 10.8 \\
\hline ICPL-20116 & 102.2 & 157.3 & 146.3 & 10.6 \\
\hline ICPH-2671 & 102.8 & 159.0 & 144.0 & 10.2 \\
\hline ICPH-2740 & 102.8 & 57.3 & 136.3 & 11.8 \\
\hline ICPH-3933 & 109.6 & 163.6 & 131.6 & 11.6 \\
\hline ICPH-3762 & 98.2 & 150.2 & 141.3 & 11.5 \\
\hline LAXMI & 97.5 & 148.5 & 147.3 & 11.2 \\
\hline BDN-2014-1 & 106.3 & 163.6 & 146.5 & 11.3 \\
\hline BDN-2011-1 & 98.2 & 150.0 & 135.5 & 11.8 \\
\hline BDN-2013-41 & 98.3 & 149.3 & 109.6 & 12.5 \\
\hline BDN-2014-2 & 105.8 & 160.6 & 116.0 & 10.3 \\
\hline BDN-2013-45 & 92.8 & 149.3 & 95.3 & 11.6 \\
\hline RVSA-15-5 & 98.3 & 153.5 & 94.2 & 10.8 \\
\hline RVSA-15-6 & 94.3 & 148.5 & 77.9 & 11.1 \\
\hline RVSA-15-10 & 93.2 & 150.8 & 84.0 & 11.0 \\
\hline TJT-501 & 93.3 & 151.3 & 91.6 & 10.6 \\
\hline IBTDREG-3 & 94.0 & 148.8 & 112.1 & 10.8 \\
\hline IBTDRG-4 & 100.6 & 155.5 & 101.6 & 11.0 \\
\hline IBTDRG-6 & 90.8 & 143.2 & 85.6 & 11.6 \\
\hline TDRG-60 & 88.8 & 139.2 & 69.1 & 11.0 \\
\hline TDRG-58 & 97.6 & 155.6 & 83.4 & 10.4 \\
\hline IBTTDRG-5 & 87.8 & 141.0 & 76.1 & 10.2 \\
\hline LRG-41 & 112.3 & 159.6 & 208.5 & 13.0 \\
\hline LRG-105 & 115.2 & 162.8 & 220.5 & 10.5 \\
\hline LRG-160 & 108.0 & 154.6 & 207.9 & 11.8 \\
\hline GRG-177 & 108.5 & 154.5 & 208.8 & 10.5 \\
\hline GRG-152 & 108.3 & 156.6 & 195.8 & 10.2 \\
\hline GRG-333 & 108.3 & 156.5 & 204.1 & 11.2 \\
\hline AGL-1603-4 & 105.6 & 155.8 & 212.8 & 11.1 \\
\hline $\mathrm{BDN}-711(\mathrm{CH})$ & 103.5 & 153.8 & 200.5 & 10.8 \\
\hline JKM-189(CH) & 113.2 & 162.2 & 227.9 & 10.7 \\
\hline TDRG-4(CH) & 104.0 & 154.0 & 206.6 & 11.5 \\
\hline TS-3R(CH) & 102.2 & 150.0 & 179.8 & 10.8 \\
\hline $\operatorname{MARUTI}(\mathrm{CH})$ & 110.0 & 161.3 & 199.3 & 10.3 \\
\hline $\mathrm{ASHA}(\mathrm{CH})$ & 103.2 & 151.0 & 202.6 & 10.6 \\
\hline Population Mean & 102.4 & 154.6 & 146.5 & 11.1 \\
\hline
\end{tabular}




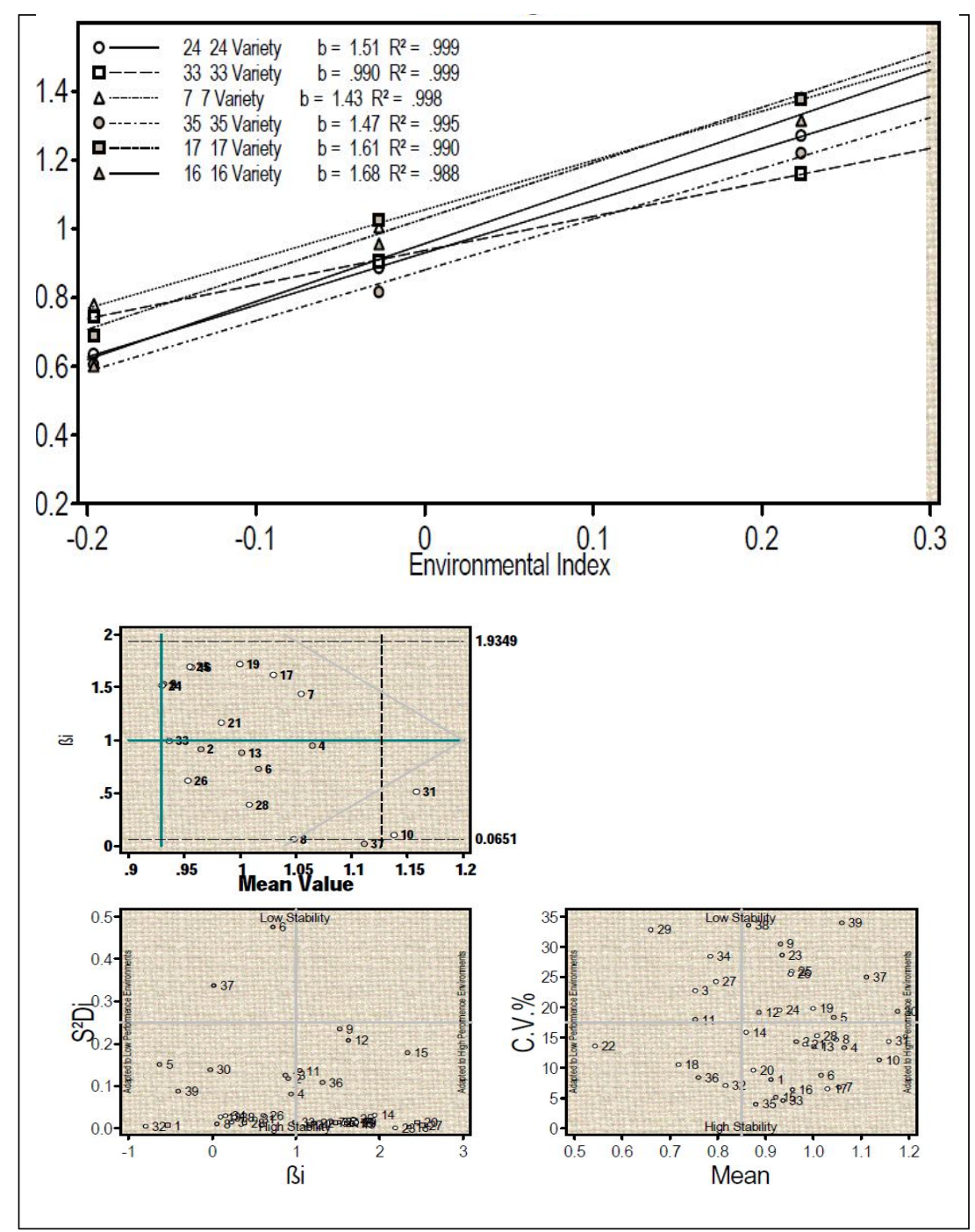

Fig 1: Environmental indices and stability parameters for seed yield (t/ ha).

regression over the environments. These findings are in accordance with Shoran et al. (1981); Muthiah and Kalaimagal (2005); Vannirajan et al. (2007); Patel et al. (2009); Sreelakshmi et al. (2010); Thanki et al. (2010); Sawargaonkar et al. (2011); Niranjan Kumar (2013); Muniswamy et al. (2017); Ramesh et al. (2017) and Manish Sharma et al. (2020).

\section{CONCLUSION}

From the present study it can be concluded that the genotype ICPL 20108 was found to be a stable for seed yield across the environments with all desirable yield and yield component features, followed by the genotypes ICPL 20098 and AGL-1603-4.The genotype GRG 152, TS-3R and ICPH2740 found suitable for unfavorable or low input environments. The stable genotype identified could be directly released after validation of results or could be used as parents in future breeding program for developing suitable genotype with wider adaptability.

\section{ACKNOWLEDGEMENT}

The authors thankful to the ICRISAT, Hyderabad, RARS Lam, (Andhra Pradesh), ARS, Badnapur, (Maharashtra), RAKCA, Sehore, (Madhya Pradesh), Indian Institute of Pulse Research (IIPR), Kanpur, (Uttar Pradesh,) PJTSAU and Tandur, (Telangana) for sharing seed materials under DAC (NFSM cell funded) project.

\section{Funding}

This research was funded by the Department of Agriculture Cooperation and Farmers Welfare, Ministry of Agriculture and Farmers Welfare, the Government of India through ICRISAT, Hyderabad.

\section{Author Contributions}

Conceptualization of research: S.Muniswamy, Rajeev K. Varshney and Rachit K. Saxena. Designing of the experiments: S.Muniswamy, Rajeev K. Varshney and Rachit K.Saxena.Contribution of experimental materials: S. Muniswamy and Rachit K. Saxena. Execution of field/lab 
experiments and data collection: S. Muniswamy and Praveen Kumar. Analysis of data and interpretation: S. Muniswamy, Praveen Kumar and Geeta. Preparation of the manuscript: S. Muniswamy, Praveen Kumar and Geeta.

\section{Conflicts of Interest:}

The authors declare no conflict of interest.

\section{REFERENCES}

Anonymous, (2017). Improved agronomic practices, UAS Dharwad and UAS Raichur, pp 100-112.

Anonymous, (2019). Project Coordinator's Report, AICRP on Pigeonpea. Pp: 23

Balakrishnan, K. and Natarajaratnam, N., (1989). Genotypeenvironment interaction for yield components in pigeonpea [Cajanus cajan (L.) Millsp.]. Madras Agricultural Journal. 76: 365-370.

Deepak, Pal, S.K., Verma Amit Kumar, G., Chauhan, C., Anandi K., Yadav H. and Harshdeep. (2020). Stability analysis in pigeonpea [Cajanus cajan (L.) Millspaugh] genotypes for yield and its component Traits. Int. J. Curr. Microbiol. App. Sci. 9(9): 264-271.

Eberhart, S.A. and Russell, W.A., (1966). Stability parameters for comparing varieties. Crop Science. 6: 36-40.

Ghodke, M.K., Jahagirdar, J.E. and Makne V.G. (1992). Phenotypic stability of newly developed pigeonpea genotypes. Indian Journal of Pulses Research. 5(2): 125-127.

Hogh-jensen, H., Myaka, F.A., Sakala, W.D., Kamalongo, D., Ngwira, A., Vesterager, J.M., Odgaard, R. and Adugyamfi, J.J., (2007). Yields and qualities of Pigeonpea varieties grown under smallholder farmers' conditions in eastern and southern Africa. African Journal of Agriculture Research. 2: 269-278.

Kumara, B.N., Dharmaraj, P.S., Kuchnur, P.H., Muniswamy, S., Yamanura, R., Diwan, J.R. and Amaresh, Y.S., (2015). Stability analysis for yield and its attributing traits in advanced genotypes of pigeonpea [Cajanus cajan (L.) Millsp.]. Legume Research. 39(2): 194-197.

Manish Sharma, Patel, P.R., Patel, M.P. and Patel, P.T. (2020). Stability analysis of yield and related traits in pigeonpea hybrids under varying agroclimatic conditions. An International Refereed, Peer Reviewed and Indexed Quarterly Journal in Science, Agriculture and Engineering. 10(34): 987-990.

Meena, S. S., Verma, S. K., Choudhary, R., Nehra, M., Panwar, R. K. and Singh J. P., (2017). Interpretation of genotype $x$ environment interaction and grain yield stability in some advance lines of pigeonpea [Cajanus cajan (L.) Millsp.] grown at different altitudes. Chemical Sciences Reviews and Letters, 6(22): 1113-1119.

Muniswamy, S., Lokesha, R., Yamanura, R. and Diwan, J. R., (2017). Stability for disease, genotype $\times$ environment interaction for yield and its components in pigeonpea [Cajanus cajan (L.) Millsp]. Legume Research. 39(1): 1-6.
Muthiah, A. R. and Kalaimagal, T., (2005). Stability analysis in hybrid pigeonpea. Indian Journal of Pulses Research. 18(1): 76-79.

Niranjana Kumara, B., (2013). Stability analysis for yield and its attributing traits in advanced genotypes of pigeonpea [Cajanus cajana. (L) Millsp.] M. Sc. (Agri.) Thesis, University of Agricultural Sciences Raichur Karnataka India. Pp:41-85

Patel, P.T., Chauhan, R.M., Parmar, L.D. and Tikka S.B.S., (2009). Phenotypic stability of yield and related traits in pigeonpea. Legume Research. 32(4): 235-239.

Patel, P.T. and Tikka, S.B.S. (2014). Gene action and stability parameters for yield and yield components, maturity duration and protein content of CGMS lines, pollen fertility restorers and their hybrids in pigeonpea. Euphytica. 199: 349-362.

Pawar, R. M., Tikka, S. B. S., Sawant, D. M. and Patil, A. D., (2013). Stability analysis for biometrical traits in pigeonpea [Cajanus cajan (L.) Millsp.]. Bioinfolet. 10(4B): 13071311.

Ramesh, S. Muniswamy, S. and Praveenkumar, B., (2017). Stability analysis for yield and its components in pigeonpea [Cajanus cajan (L.) Mill sp.] under rainfed Conditions. Int. J. Curr. Microbiol. App. Sci., 6(5): 1134-1144.

Sawargaonkar, S.L., Saxena, K.B., Madrap, I.A. and Rathore, A., (2011). Stability analysis of yield and related traits in pigeonpea hybrids. Journal of Food Legume. 24(3): 184-193.

Shoran, J.B., Pandya, B.P. and Gautam, P.L. (1981). Genotype $\times$ environment interaction analysis in pigeonpea. Crop Improvement. 8: 33-36.

Singh, J., Kumar, A. and Fiyaz, R.A.(2015). Diversity and stability analysis for yield and component traits in (Cajanus cajan) under rainfed conditions. Legume Reserarch. 38(2): 169173.

Sreelakshmi, C., Sameer Kumar,C.V. and Shivani, D. (2010). Genetic analysis of yield and its component traits in drought tolerant genotypes of pigeonpea [Cajanus cajan (L.) Millsp.]. Electronic Journal of Plant Breeding. 1(6): 1488-1491.

Thanki, H.P., Sawargaonkar, S.L. and Hudge, B.V. (2010). Genotype $\times$ environment interaction for biometrical traits in pigeonpea [Cajanus cajan (L.) Millsp.] under varying spacing. Electronic Journal of Plant Breeding.1(4): 925928.

Vannirajan, C., Rangasamy, P. and Nepolean, T. (2007). Stable and unstable Pigeonpea genotypes for yield versus component characters. Plant Archives. 7(1): 427-428.

Varshney, R.K., Saxena, R.K., Upadhyaya, H.D., Khan, A.W., Yu Y., Kim, C., Rathore, A., Kim, D., Kim, J., An S., Kumar, V., Anuradha, G., Yamini, K. N., Zhang, W., Muniswamy, S., Kim, J.S., Penmetsa, R.V., Wettberg, E.V., Datta, S. K. (2017). Whole-genome resequencing of 292 pigeonpea accessions identifes genomic regions associated with domestication and agronomic traits.Nature Gentics. 49: 1082-1088 